Article

\title{
Oral Health Condition of Children Living with HIV
}

\section{Natália Spillere Rovaris ${ }^{1}$, Luiz Gustavo Teixeira Martins ${ }^{2}$ and Jefferson Traebert ${ }^{3,} *$}

1 University of Southern Santa Catarina - UNISUL, Avenida José Acácio Moreira, 787; 88704-900, Tubarão, Santa Catarina, Brazil; E-Mail: natispillere@gmail.com

2 University of Southern Santa Catarina - UNISUL, Rua Fiuza da Rocha, 580; 88801-400, Criciúma, Santa Catarina, Brazil; E-Mail: lgtmdm@hotmail.com

3 University of Southern Santa Catarina - UNISUL, Avenida José Acácio Moreira, 787; 88704-900, Tubarão, Santa Catarina, Brazil; E-Mail: jefferson.traebert @unisul.br

* Author to whom correspondence should be addressed; E-Mail: jefferson.traebert@gmail.com.

Received: 30 September 2013; in revised form: 12 November 2013 / Accepted: 22 November 2013/ Published: 21 January 2014

\begin{abstract}
Background: AIDS progression is faster in children than adults. Little is known about the oral health status of children living with HIV. Aim: To carry out a literature review about the oral health conditions of children living with HIV in order to observe if this specific population presents different oral health conditions compared to children without HIV infection. Methods: A documental study of literature review was carried out. Studies were searched at PubMed using "oral health", "children", "HIV" and "AIDS" as keywords. Papers published between 2001 and 2011 were included. After applying the exclusion criteria and complete reading of the selected studies, other articles were selected from the references lists of the first ones. Results: Firstly, 24 studies were identified. Among them, $65.5 \%$ were excluded according to the exclusion criteria. From the five selected articles, another five from the references of these were included. Only one article compared the oral health conditions of children living with HIV with controls without HIV infection. Conclusions: Only 10 papers contained information on the oral health conditions of children living with HIV, and just one compared the results with controls. The few studies found were insufficient to establish the oral health condition profile of children living with HIV. This lack of information could represent the lack of interest of researchers and health authorities in more integrative care and can result in neglect with this specific population of children.
\end{abstract}

Keywords: oral health; children; HIV; AIDS 


\section{Introduction}

One child is infected by HIV each minute around the world [1]. Most HIV infection cases occur by the vertical path. There is evidence that about $65 \%$ of cases occur late in pregnancy, mainly during childbirth. The remaining 35\% occur intrauterine, mainly in the last weeks of pregnancy. Breastfeeding is contraindicated, because it represents an additional transmission risk from $7 \%$ to $22 \%$, which is increased with each exposure to breastfeeding [2,3].

There are reported cases of HIV infection by sexual abuse in children, which is especially important. In this situation, the risk of infection from sexual intercourse with an infected partner is estimated to be about $0.1 \%$ to $0.3 \%$. However, this kind of risk in childhood and adolescence is potentially higher due to the lower thickness of vaginal epithelium in young girls, cervical ectopia in adolescents, trauma and the occurrence of other sexually transmitted diseases [4].

AIDS progression is faster in children than adults [3]. The variation in the disease progression is related to the period of infection, the viral load at equilibrium, the viral genotype and phenotype, the body's immune response and the individual genetic constitution [4]. The child presents primary viremia in early life due to the immature immune system, making him/her susceptible to an immunological dysfunction framework and, consequently, to developing opportunist infections [3,4], like candidiasis. Other orofacial disorders can occur, such as cervicofacial lymphadenopathy, salivary gland increase, xerostomia, oral herpetic stomatitis, petechiae and gingivitis [5,6].

Among children living with HIV, the prevalence of caries and gingival problems is unclear. However, there is a potential for these to be increased [7]. This can occur due to the higher consumption of medicines with sugar content, the higher consumption of sweetened foods, inadequate hygiene habits, decreased salivary flow and, consequently, the decreased buffer capacity of saliva and of electrolytes and proteins, which inhibit cariogenic microorganism growth.

On the other hand, the use of antiretroviral therapy is pointed to as one reason that contributes significantly to the decrease of oral lesions in soft tissues in children living with HIV [8]. Antiretroviral therapy in children aims to reduce morbimortality, improve quality of life, ensure adequate growth and development, preserve, improve or reconstitute the immunologic system in order to reduce the occurrence of opportunist infections and provide maximum and prolonged suppression of HIV replication, reducing the risk of resistance to antiretroviral therapy [3].

Little is known about the oral health status among children living with HIV. Changes in oral health conditions can affect the quality of life, complicate treatment systems and create or exacerbate nutritional and psychosocial problems [9]. The objective of this study was to extensively review the literature regarding this theme, aiming to point out a framework for the oral health conditions of children living with HIV.

\section{Methods}

This is a documental study of literature review. Studies were searched at PubMed using "oral health", "children", "HIV" and "AIDS" as keywords. Papers published between 2001 and 2011 were included first. After, the following exclusion criteria were applied: studies not including oral health clinical conditions, literature revisions and other non-scientific reports. 
After the complete reading of each article that was found, other articles were selected from the references of those articles. These strategies are shown in Figure 1.

Figure 1. Methodological flowchart of the search for articles.

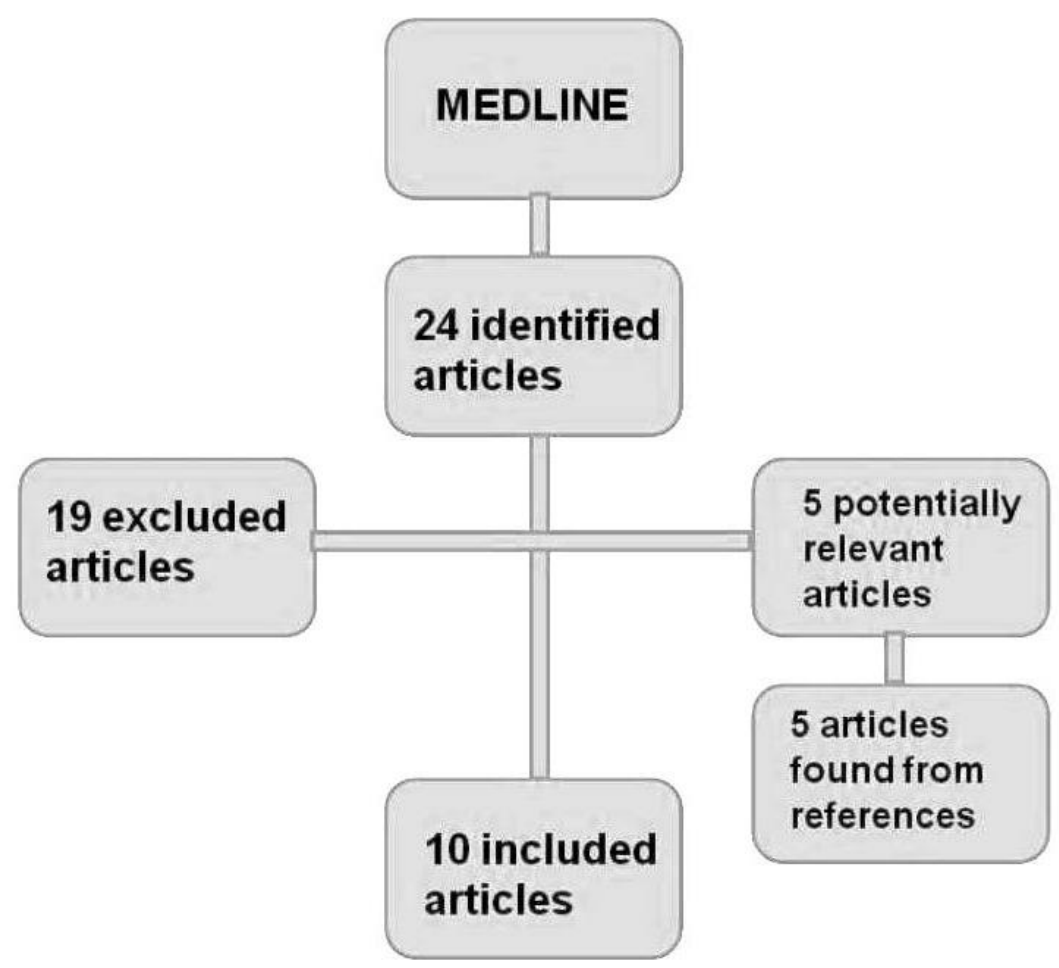

All selected articles were read and analyzed in relation to the methodological design and the main results. This information was summarized according to the year of publication, study aim, sample, age group and main reported results.

\section{Results}

Firstly, 24 studies were identified. Among them, $19(65.5 \%)$ were excluded according to the exclusion criteria. From the five selected articles, another five were included, which were selected from the reference lists of the original five articles.

Only one article compared the oral health conditions of children living with HIV with controls without HIV infection. The characteristics of this study and of all other included studies are presented in Table 1. 
Table 1. Studies on the oral health clinical conditions of children living with HIV (2001-2011).

\begin{tabular}{|c|c|c|c|}
\hline Author (Year) & Aims & Sample and Age Group & Main Results and Conclusions \\
\hline Portela et al. (2001) [10] & $\begin{array}{l}\text { Determining the gingival health } \\
\text { condition and its relation with the } \\
\text { number of leukocytes and } \\
\text { immunosuppression degree. }\end{array}$ & $\mathrm{n}=35$ & $\begin{array}{l}\text { - gingival changes: } 80 \% \text {; } \\
\text { - linear gingival erythema: } 8.6 \% \text {; from them, all } \\
\text { presented with severe immunosuppression } \\
\text { and leukopenia; } \\
\text { - the frequency of patients with leukopenia and } \\
\text { severe immunosuppression was higher in those with } \\
\text { some gingival change. }\end{array}$ \\
\hline Grando et al. (2002) [11] & $\begin{array}{l}\text { Evaluating the prevalence of } \\
\text { oral manifestations. }\end{array}$ & $\begin{array}{l}\quad n=184 \\
\text { zero to } 13 \text { years old }\end{array}$ & $\begin{array}{l}\text { - cervicofacial lymphadenopathy: } 94.0 \% \text {; } \\
\text { - increase of parotid volume: } 39.7 \% \text {; } \\
\text { - erythematous candidiasis: } 29.4 \% \text {; } \\
\text { - petechiae: } 16.9 \% \text {; } \\
\text { - gingivitis: } 11.7 \% \text {; } \\
\text { - xerostomia: } 11.0 \% \text {; } \\
\text { - angular cheilitis: } 10.2 \% \text {. }\end{array}$ \\
\hline Fabro et al. (2002) [5] & $\begin{array}{l}\text { Evaluating dental and } \\
\text { mucosa conditions. }\end{array}$ & $\begin{array}{l}\quad \mathrm{n}=105 \\
\text { zero to } 12 \text { years old }\end{array}$ & $\begin{array}{l}\text { - dmf-t average: } 6.3 ; \\
\text { - DMF-T average: } 1.8 ; \\
\text { - increase of parotid volume: } 35.2 \% \text {; } \\
\text { - acute pseudomembranous candidiasis: } 34.3 \% \text {; } \\
\text { - cervical lymphadenopathy: } 32.4 \% \text {. }\end{array}$ \\
\hline Ribeiro et al. (2002) [7] & $\begin{array}{l}\text { Evaluating if the quality and quantity } \\
\text { of biofilm represent important factors } \\
\text { in caries activity and gingivitis. }\end{array}$ & $\begin{array}{l}\quad n=56 \\
\text { zero to } 14 \text { years old }\end{array}$ & $\begin{array}{l}\text { - visible biofilm: } 87.5 \% \text {; } \\
\text { - gingivitis: } 58.9 \% \text {; } \\
\text { - active caries lesions: } 73.2 \% \text {; } \\
\text { - quality and quantity of biofilm on dental surfaces } \\
\text { represent important factors in etiologic caries } \\
\text { activity and gingivitis. }\end{array}$ \\
\hline
\end{tabular}


Table 1. cont.

\begin{tabular}{|c|c|c|c|}
\hline Author (Year) & Aims & Sample and Age Group & Main Results and Conclusions \\
\hline $\begin{array}{c}\text { Álvarez Loureiro et al. (2007) } \\
{[12]}\end{array}$ & $\begin{array}{l}\text { Determining the oral health state of } \\
\text { Uruguayan children. }\end{array}$ & $\begin{array}{l}\quad n=76 \\
\text { one to } 17 \text { years old }\end{array}$ & $\begin{array}{l}\text { - dmf-t: } 4.52 \pm 6.2 \text { in the deciduous dentition and } \\
4.42 \pm 3.35 \text { in the mixed dentition; } \\
\text { - DMF-T: } 1.28 \pm 1.72 \text { in the mixed dentition and } \\
2.8 \pm 2.4 \text { in the permanent dentition; } \\
\text { - any kind of malocclusion: } 51.8 \% \text {; } \\
\text { - gingivitis: } 75.0 \% \text {; } \\
\text { - candidiasis: } 16.0 \% \text {; } \\
\text { - herpetic lesions: } 8.0 \% \text {; } \\
\text { - parotid gland hypertrophy: } 11.6 \% \text {; } \\
\text { - pilous leukoplakia: } 2.4 \% \text {; } \\
\text { - GUNA: } 0.7 \% \text {. }\end{array}$ \\
\hline Blignaut (2007) [13] & $\begin{array}{l}\text { Determining the needs of children's } \\
\text { oral health. }\end{array}$ & $\begin{array}{l}\qquad \mathrm{n}=87 \\
\text { three to seven years old }\end{array}$ & $\begin{array}{l}\text { - early caries: } 21.8 \% \\
\text { - severe pain: } 5.7 \% \\
\text { - candidiasis: } 13.8 \% \\
\text { - bleeding associated with oral mucosa } \\
\text { ulceration: } 4.6 \%\end{array}$ \\
\hline Dornelas et al. (2008) [6] & $\begin{array}{l}\text { Verifying the prevalence of orofacial } \\
\text { manifestations and its correlation with } \\
\text { immunological classification. }\end{array}$ & $\begin{array}{l}\qquad n=21 \\
\text { two to } 12 \text { years old }\end{array}$ & $\begin{array}{l}\text { - orofacial manifestations: } 71.4 \% ; \\
\text { - cervicofacial lymphadenopathy: } 28.5 \% \text {; } \\
\text { - parotid gland hypertrophy: } 23.8 \% ; \\
\text { - pseudomembranous candidiasis: } 19.0 \% \text {; } \\
\text { - angular cheilitis: } 19.0 \% \text {; } \\
\text { - linear gingival erythema: } 4.7 \% \text {; } \\
\text { - oral lesions more prevalent among those who } \\
\text { presented severe immunosuppression: } \\
\text { pseudomembranous candidiasis }(60.0 \%) ; \\
\text { - significant statistical correlation }(p=0.039) \\
\text { among oral manifestations and the } \\
\text { immunosuppression degree. }\end{array}$ \\
\hline
\end{tabular}


Table 1. cont.

\begin{tabular}{|c|c|c|c|}
\hline Author (Year) & Aims & Sample and Age Group & Main Results and Conclusions \\
\hline Sowole et al. (2009) [14] & $\begin{array}{l}\text { Evaluating oral manifestations, the } \\
\text { oral health state and the need } \\
\text { for treatment. }\end{array}$ & $\begin{array}{c}\qquad \mathrm{n}=55 \\
\text { six months to } 16 \text { years old }\end{array}$ & $\begin{array}{l}\text { - good oral hygiene: } 69.1 \% \\
\text { - gingivitis: } 25.5 \% \\
\text { - caries: } 30.9 \% \\
\text { - restoration treatment need: } 38.2 \% \\
\text { - most frequent oral lesion: candidiasis. }\end{array}$ \\
\hline Kelly et al. (2009) [15] & $\begin{array}{l}\text { Determining the risk factors and the } \\
\text { prevalence of caries in an HIV- } \\
\text { infected children group (GI) and in } \\
\text { children without HIV infection (GII). }\end{array}$ & $\begin{array}{l}\text { GI: } n=133 ; \text { age average } 6.8 \\
\quad \text { years old } . \\
\text { GII: } n=85 ; \text { age average } 8.1 \\
\text { years old. }\end{array}$ & $\begin{array}{l}\text { - no significant difference in dmf-t/DMF-T; } \\
\text { - dmf-t: } 6.4(\mathrm{GI}) \text { and } 8.0(\mathrm{GII}) \text {; } \\
\text { - DMF-T: } 1.0(\mathrm{GI}) \text { and } 1.4(\mathrm{GII}) \text {; } \\
\text { - significant association between dmf-t and the habit } \\
\text { of eating sucrose between meals ( } p<0.05) \text {, } \\
\text { although, in the GI group, this habit was } \\
\text { more frequent; } \\
\text { - } 78.9 \% \text { of GI used combined antiretroviral } \\
\text { therapy, and this medicine presented a high } \\
\text { cariogenic potential. }\end{array}$ \\
\hline Damle et al. (2010) [16] & $\begin{array}{l}\text { Evaluating gingival conditions, caries } \\
\text { and lesions in the oral mucosa related } \\
\text { to CD4 counting. }\end{array}$ & $\begin{array}{l}\quad n=234 \\
\text { two to } 15 \text { years old }\end{array}$ & 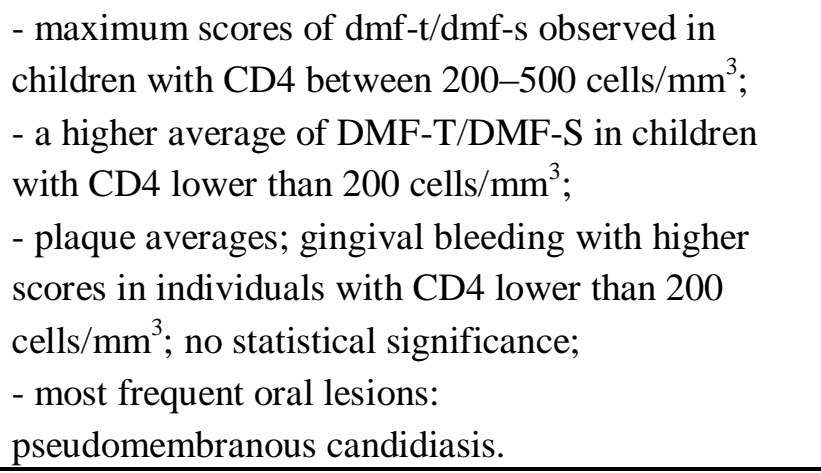 \\
\hline
\end{tabular}




\section{Discussion}

This review was performed aiming to observe if children living with HIV present a different oral health status compared to those without HIV infection. However, only 10 papers contained information on the oral health conditions of children living with HIV, and only one compared the results with controls of children without HIV infection. It seems that these numbers are insufficient to draw a panorama of the oral health conditions of children living with HIV.

The lack of studies involving this specific population of children represents a lack of interest of dental researchers and public health policy makers in providing information for planning integrative care to children living with HIV. Knowing if these children have or do not have a different oral health profile is essential, since they are exposed to different health situations that could raise their risk of developing dental caries, gingivitis, opportunist infections and other oral conditions. One example could be the antiretroviral therapy prescribed in sweetened oral solution medicines that represents a higher risk for enamel demineralization and, therefore, caries development. Another example could be related to the immature immune system, making the child susceptible to an immunological dysfunction framework and, consequently, to developing opportunist infections.

However, considering this panorama, it becomes important to describe and to discuss the few studies found. Some of them $[5,12,13,14,16]$ evidenced general conditions of oral health, including dental conditions and oral mucosa conditions. The results have shown that children living with HIV present a high prevalence of dental caries and manifest oral soft tissues lesions related to HIV infection. Nevertheless, these studies did not compare the prevalence of caries with control children without HIV infection. Due to this methodological limitation, the eventual difference in caries prevalence remains unclear. Howsoever, the high prevalence of caries is noticed when it is compared to the goal established by the World Health Organization (WHO) [17] for 2010: a maximum of one tooth with caries per child in the age group from zero to 12 years old. This goal is for all children and does not mention children living with HIV.

Only one study compared the prevalence of caries in children living with HIV with controls. Kelly et al. [15] concluded that both groups presented exposure to several risk factors for caries, and both presented a high prevalence of the disease. The chronic use of medicine using sweetened vehicles could be considered as a relevant factor for children living with HIV in addition to other classical etiologic factors for dental caries. However, in the group of children without HIV infection, the habit of sucrose intake between meals was demonstrated to be an important factor related to the high prevalence of caries.

In relation to malocclusion, only one study was found. Álvarez Loureiro et al. [12] found a prevalence of $52 \%$ without detailing which kinds of malocclusion were found to be more common. It is also important to notice that this study did not mention a control group. This fact points to the impossibility of elucidating if children living with HIV present a different malocclusion status compared to those without HIV.

Concerning periodontal diseases, as the immune system becomes weaker, the individual becomes more susceptible to periodontal diseases [18]. Indeed, Portela et al. [10] showed that four-to nine-year-old children with leukopenia and severe immunosuppression presented more gingival 
alterations. Gingivitis and linear erythema were the more frequent periodontal diseases reported by Alves et al. [19].

In individuals living with HIV, about $40 \%$ of the signals and symptoms are located in the head and neck regions [11]. Candidiasis [5,11,12,13,14,16], cervicofacial lymphadenopathy [5,6,11], the increase of parotid volume [5,6,11,12], petechiae [11], xerostomia [11] and herpetic lesions [12] were the most frequent soft tissue lesions related to HIV in children living with this condition.

Candidiasis is the most frequent opportunistic disease that affects people living with HIV. Undoubtedly, about $90 \%$ of individuals who live with HIV present at least one oropharyngeal candidiasis episode during the period with AIDS [20]. It can appear in the pseudomembranous form, erythema or angular cheilitis. In these individuals, the lesions are more severe and are more resistant to conventional treatment. The lesions are much more extensive, and they can scatter to the esophagus. The presence of candidiasis scattered to the esophagus is one of conditions that can define AIDS in people living with HIV, and it is considered a signal of disease evolution [20].

Cervicofacial lymphadenopathy is a very important condition for differential diagnosis and is an orofacial manifestation very frequent in children living with HIV. It is characterized by the increase of the floating volume of lymphnodes, and the diagnosis can be defined by the palpation of them. It can be part of a generalized lymphadenopathy [11].

The increase of the salivary glands, mainly the parotid, can be related to changes in the immunologic state or related to infections by cytomegalovirus or Epstein-Barr. However, this is not clear enough [19]. Xerostomia is one of the main complaints of people living with HIV. Guggenheimer and Moore [21] point out that xerostomia is a very uncomfortable condition, leading to severe oral repercussion, like cervical caries and a high incidence of oral candidiasis. The presence of oral herpetic lesions is reported in the study [19]. The main characteristic of herpetic infection in children living with HIV is the lesion relapse, becoming chronic with larger lesions, scattered and with a longer duration [19]. The presence of oral leukoplakia is rare in children [19]; however, Álvarez Loureiro et al. [12] demonstrated a prevalence of $2.4 \%$ in their study.

As oral manifestations of AIDS commonly occur prior to systemic manifestations, the early diagnosis of oral lesions, clearly and precisely done by health professionals, including dentists, becomes indispensable. A condition of performing a precise early diagnosis is the existence of enough knowledge and research on the oral health conditions of people living with HIV, especially children.

Some limitations should be considered when analyzing the results of this study. Probably the main one is the restricted period of data collection. This may represent a period in which the consequences of the disease have been minimized, such as by the use of anti-retroviral drugs, with the consequent reduction of HIV-related oral conditions.

It can be concluded that the few studies found are insufficient to establish the profile of the oral health conditions of children living with HIV. This lack of information could represent the lack of interest of researchers and health authorities for a more integrative care and can result in neglect with this specific population of children.

\section{Conflicts of Interest}

The authors declare no conflict of interest. 


\section{References}

1. Ministério da Saúde (BR). Secretaria de Atenção a Saúde. Departamento de Atenção básica. HIV/AIDS, Hepatites e outras DST. Cadernos de Atenção Básica. Série A. Normas e Manuais Técnicos. n.18. Brasília: Ministério da Saúde; 2006.

2. Schaurich, D.; Medeiros, H.M.F.; Motta, M.G.C. Vulnerabilidades no viver de crianças com AIDS. Rev. Enferm. UERJ 2007, 15, 284-290.

3. UNICEF. UNAIDS. World Health Organization. Children and Aids: A stocktaking report. Genebra: UNICEF; 2007.

4. Ministério da Saúde (BR). Secretaria de Vigilância em Saúde. Programa Nacional de DST e AIDS. Recomendações para terapia Antirretroviral em crianças e Adolescentes infectados pelo HIV. Série Manuais. n.85. Brasília: Ministério da Saúde; 2009.

5. Ministério da Saúde (BR). Secretaria de Vigilância em Saúde. Programa Nacional de DST e AIDS. Guia de tratamento clínico da infecção pelo HIV em pediatria. $3^{\mathrm{a}} \mathrm{ed}$. Brasília: Ministério da Saúde; 2007.

6. Fabro, S.M.L.; Ody, E.; Grando, L.J.; Peres, K.G.A.; Rath, I.B.S. Alterações estomatológicas e condições dentais em crianças infectadas pelo HIV. Arq. Odontol. 2002, 38, 163-252.

7. Dornelas, S.K.L.; Bertazzoli, R.C.B.; Medeiros, M.B.; Biase, R.C.C.G.; Rosa, M.R.D. Manifestações orofaciais e sua correlação com a classificação clínica e imunológica em crianças infectadas pelo HIV em João Pessoa, Paraíba, Brasil. Pesqui. Bras. Odontoped. Clin. Integr. 2008, 8, 179-183.

8. Ribeiro, A.A.; Portela, M.; Souza, I.P. Relação entre biofilme, atividade de cárie e gengivite em crianças HIV+. Pesqui. Odontol. Bras. 2002, 16, 44-50.

9. Cavassani, V.G.S.; Andrade Sobrinho, J.; Homem, M.G.N.; Rapoport, A. Candidíase oral como marcador de prognóstico em pacientes portadores do HIV. Rev. Bras. Otorrinolaringol. 2002, 68, 630-634.

10. Machado, F.C.; Souza, I.P.R.; Tura, L.F.R.; Castro, G.F. Adesão a um programa de atenção à saúde bucal para crianças e adolescentes infectados pelo HIV e atitude dos responsáveis. Ciênc. saúde coletiva. 2008, 13, 1851-1857.

11. Portela, M.B.; Castro, G.F.; Souza, I.P.R.; Silva, R.H.O. Relação entre saúde gengival e condição sistêmica em crianças infectadas pelo HIV. Rev. Bras. Odontol. 2001, 58, 88-91.

12. Grando, L.J.; Yurgel, L.S.; Machado, D.C.; Silva, C.L.; Menezes, M.; Picolli, C. Manifestações estomatológicas, contagem de linfócitos T-CD4+ e carga viral de crianças brasileiras e norte americanas infectadas pelo HIV. Pesqui. Odontol. Bras. 2002, 16, 18-25.

13. Álvarez Loureiro, L.A.; Hermida, L.; Cuitiño, E. Situación de salud oral de los niños uruguayos portadores del vírus de la inmunodeficiencia humana. Arch. Pediatr. Urug. 2007, 78, 23-28.

14. Blignaut, E. Oral health needs of HIV/AIDS orphans in Gauteng, South Africa. AIDS Care 2007, $19,532-538$.

15. Sowole, C.A.; Orenuga, O.O.; Naidoo, S. Access to oral health care and treatment needs of HIV positive paediatric patients. Pesq. Bras. Odontoped. Clin. Integr. 2009, 9, 141-146.

16. Kelly, A.; Soares, L.F.; Pomarico, L.; Souza, I.P.R. Risco e atividade de cárie em crianças com e sem infecção pelo HIV. RGO 2009, 57, 217-222. 
17. Damle, S.G.; Jetpurwala, A.K.; Saini, S.; Gupta, P. Evaluation of oral health status as an indicator of disease progression in HIV positive children. Pesq. Bras. Odontoped. Clin. Integr. 2010, 10, 151-156.

18. Organização Mundial da Saúde. Levantamento Básico em Saúde Bucal. 4th ed. São Paulo: Santos, Brazil, 1999.

19. Vieira, T.R.; Péret, A.C.A.; Péret Filho, L.A. Alterações periodontais associadas às doenças sistêmicas em crianças e adolescentes. Rev. Paul. Pediatr. 2010, 28, 237-243.

20. Alves, F.B.T.; Czlusniak, G.D.; Dal'Maso, A.M.S.; Shimizu, K.H.; Verri, M.A. Lesões estomatológicas em crianças HIV positivas e suas implicações clínicas. Arq. Odontol. 2009, 45, 191-198.

21. Favalessa, O.C.; Martins, M.A.; Hahn, R.C. Aspectos micológicos e suscetibilidade in vitro de leveduras do gênero Candida em pacientes HIV-positivos provenientes do Estado de Mato Grosso. Rev. Soc. Bras. Med. Trop. 2010, 43, 673-677.

22. Chimenos, E.; Lopez, P.D. Fármacos antifúngicos utilizados em el tratamiento de la micosis. Med. Oral. 1998, 3, 78-90.

23. Guggenheimer, J.; Moore, P.A. Xerostomia: etiology, recognition and treatment. J. Am. Dent. Assoc. 2003, 134, 61-69.

(C) 2014 by the authors; licensee MDPI, Basel, Switzerland. This article is an open access article distributed under the terms and conditions of the Creative Commons Attribution license (http://creativecommons.org/licenses/by/3.0/). 